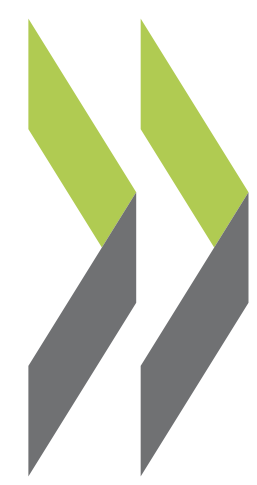

PEB Exchange, Programme on Educational Building 2008/12

$$
\begin{array}{r}
\text { Open Plan Schools } \\
\text { in Portugal: Failure or } \\
\text { Innovation? }
\end{array}
$$

\section{Miguel Martinho,}

\section{José M. R. Freire da Silva}




\section{Open Plan Schools in Portugal: Failure or Innovation?}

\section{ESCOLA DA PONTE, AN EXEMPLARY CASE}

By Miguel Martinho and José Freire da Silva, Ministry of Education, Portugal

Open plan schools have been largely contested in Portugal; many teachers, administrators and even parents consider this model of schooling inappropriate and therefore a failure. Recently however the Escola da Ponte, one of the open plan schools that has survived, was recognised as one of the country's most innovative educational facilities. Curiously, one of the main reasons for the school's "success", in the opinion of its teaching staff, is precisely the open space design.

\section{Escola da Ponte}

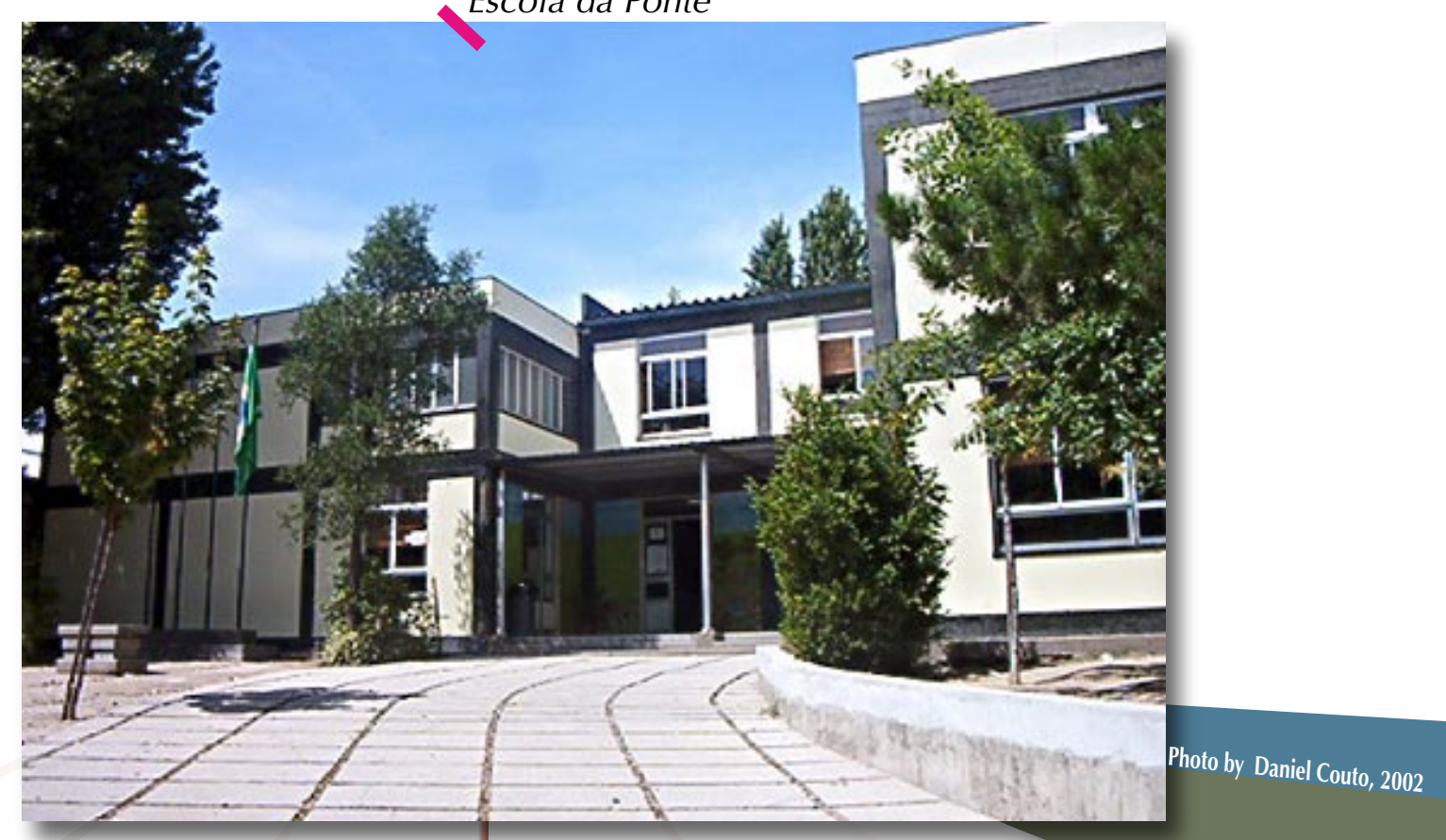




\section{THE OPEN PLAN CONCEPT}

An open plan school, simply defined, is "a school built to a design which does not include self contained classrooms" (Hamilton, 1976). It has fewer internal doors and walls than a school with traditional classrooms accommodating the same number of students. The open space design, often still used in the business world, was popular for schools in the 1960s and 1970s, especially in North America and Scandinavia though the concept spread around the world.

According to Brogden (2007, p. 59), it was in the United Kingdom that the first primary school designated as open plan appeared. The school, built in 1959 at Finmere, was designed by David Medd in collaboration with teachers and administrators. Pearson says of the school:

Instead of offering the conventional, anonymous, box-type classroom solution, they deliberately broke up the space into a number of linked learning areas, each with a special function and character which positively invited a particular activity. Though the design aroused the criticism that architects were determining an educational pattern, all decisions were made in close collaboration with the authority's officers and teachers. Variety of educational opportunity was the keynote of the whole design, and the object was to produce a building which, in the hands of discerning teachers, contributed to the processes of learning and maturing. (Pearson, 1972)

Following World War II, the concern for lowering costs inevitably led to a new approach to school design. According to Hyland (1980), during the period after 1950 the rationalisation of building design resulted in reducing the space per child without reducing the actual teaching space. Innovations at that time included lower ceilings, dual purpose areas (combining the hall and the dining space) and a smaller total area by combining corridors with classroom space.

Lowering construction costs was no doubt an important issue in early open plan projects, but it was not the only one. The possibility to implement different pedagogical ideas and to offer more flexible and polyvalent spaces was also important.

Thus, two aspects gave birth to the open plan schools: an economic concern and the influence of progressive educational ideas. These ideas - including the breakdown of the class as the basic unit of teaching, grouping exercises according to centres of interest, individualised teaching and the importance of an adequate environment (highly emphasised by Maria Montessori) - were already defended by the "New Education" movement about a century ago. The new concept of open space in school design absorbed these progressive educational trends.

\section{REJECTION OF THE OPEN SPACE DESIGN}

However, the open space concept was unacceptable to some teachers, administrators and architects who did not want such a radical change in schools. The concept of flexible spaces with movable walls, where the open space could constantly adapt to the changing needs of the educational teams (team teaching was another important feature), created strong resistance in some schools:

In the following years most open plan schools returned to the old and comfortable programs. Open space was chopped up into classrooms with doors that could be shut. This happened to most of the open plan schools - most but not all. Some open space schools have survived. We'd guess that only a small percentage of these schools are still "open", and a few more have been built in recent years. Others are being planned. (Brubaker, 1998) 
Many reasons can account for the rejection of this innovative architectural plan. The culture of individualism in teachers is one of them, as pointed out by Hargreaves (1988); it is a natural tendency to teach in the same way that one has learned. But recent surveys (Martinho, 2008; Brogden, 2007) also show evidence that teachers (the main actors in this process) were not properly prepared for a pedagogy that was intended to be innovative. Brogden (2007, p. 63) advances that "little or no attention" was given to training teachers for this new paradigm.

\section{ADVANTAGES}

While these schools may not have met all the conditions to function properly, it was not impossible for them to work well. In fact, some teachers believe that the advantages of the open space design compensate for the risks and difficulties involved. Neville Bennett, who has done extensive research on open space schools, told the authors of this article that he "came to the conclusion that some designs were better than others and that they could work well provided that teachers were aware of the possibilities of space use and were well organised".

Even in a highly technological environment, the concept can be successful. The authors had the chance to put into practice pedagogical principles such as team teaching and working with small groups of students on various subjects in the Lisbon Communications Museum's Escola do Futuro (School of the Future). Of those students, $95 \%$ preferred such flexible types of teaching to traditional and $100 \%$ found it offered more advantages and facilitated learning.

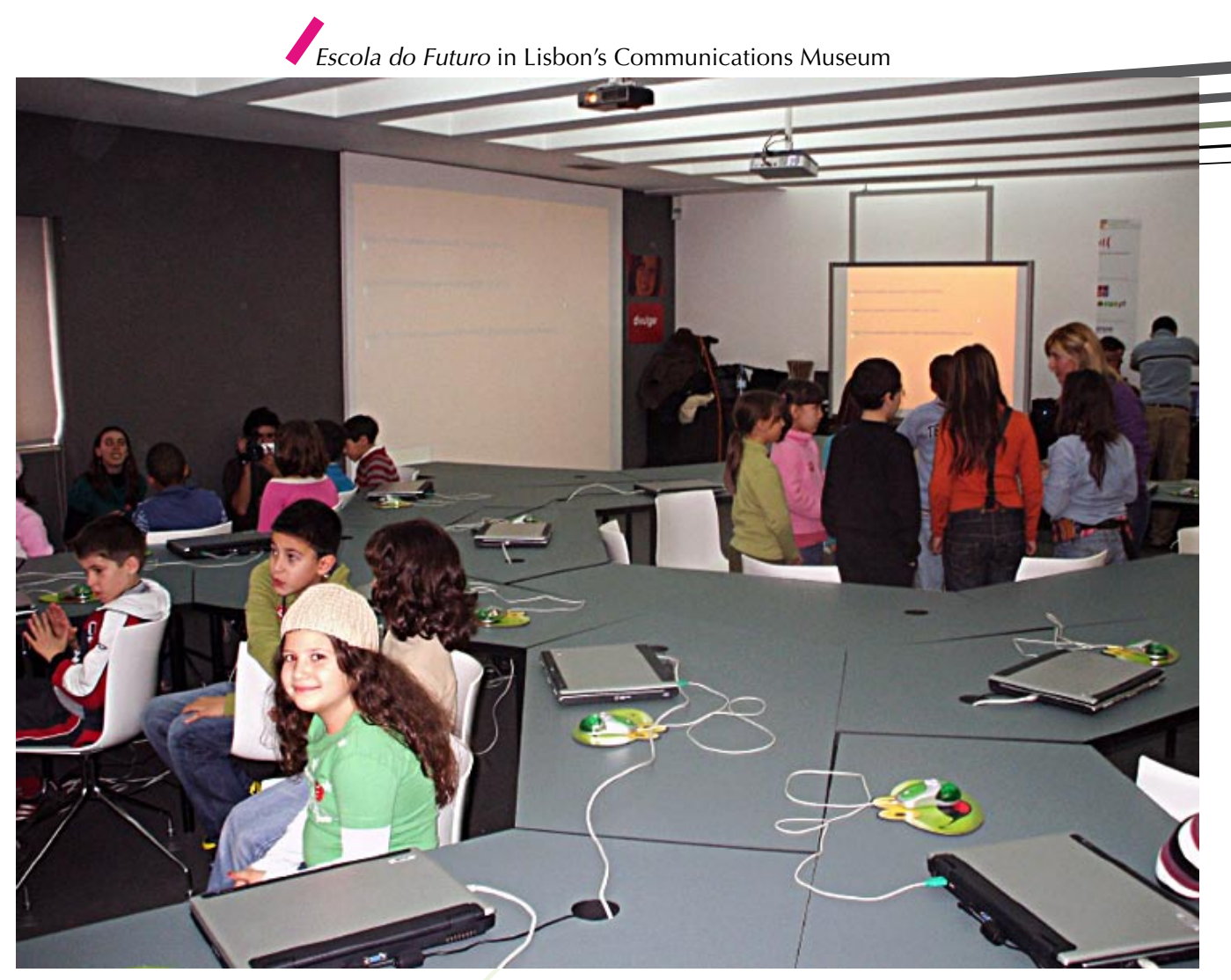




\section{TOWARDS OPEN PLAN SCHOOLS IN PORTUGAL}

In the 1960s, the OECD Mediterranean Region Project played a major role in developing Portugal's school architecture. For that project, a group of architects, engineers and pedagogical consultants was set up under the direction of an English architect named Guy Oddie. The group became part of an OECD project known as DEEB (Development and Economy in Educational Building), in which teams from other countries - Greece, Spain, Turkey and Yugoslavia - took part.

As a result of that collaboration, a pilot school was built in Mem Martins and inaugurated in 1966 (see plan below). The team researched new pedagogical concepts and new relationships between school space and student activities. (The reform of Portugal's school programmes was also a consequence of that collaboration [Felgueiras, 2007]). Although the pilot school was not an open plan, it presented innovative characteristics for the time, the most evident being a bigger teaching area than the previous standard project and a multi-purpose hall (for physical education, dance, theatre, films, a library, exhibitions, conferences and a canteen).

The Mem Martins school was designed with four classrooms articulated around a central patio and showed a new concern for flexibility, especially in the use of the working areas. Although the gross floor area had decreased compared to traditional design solutions, the educational floor area per student had increased.

\section{4}

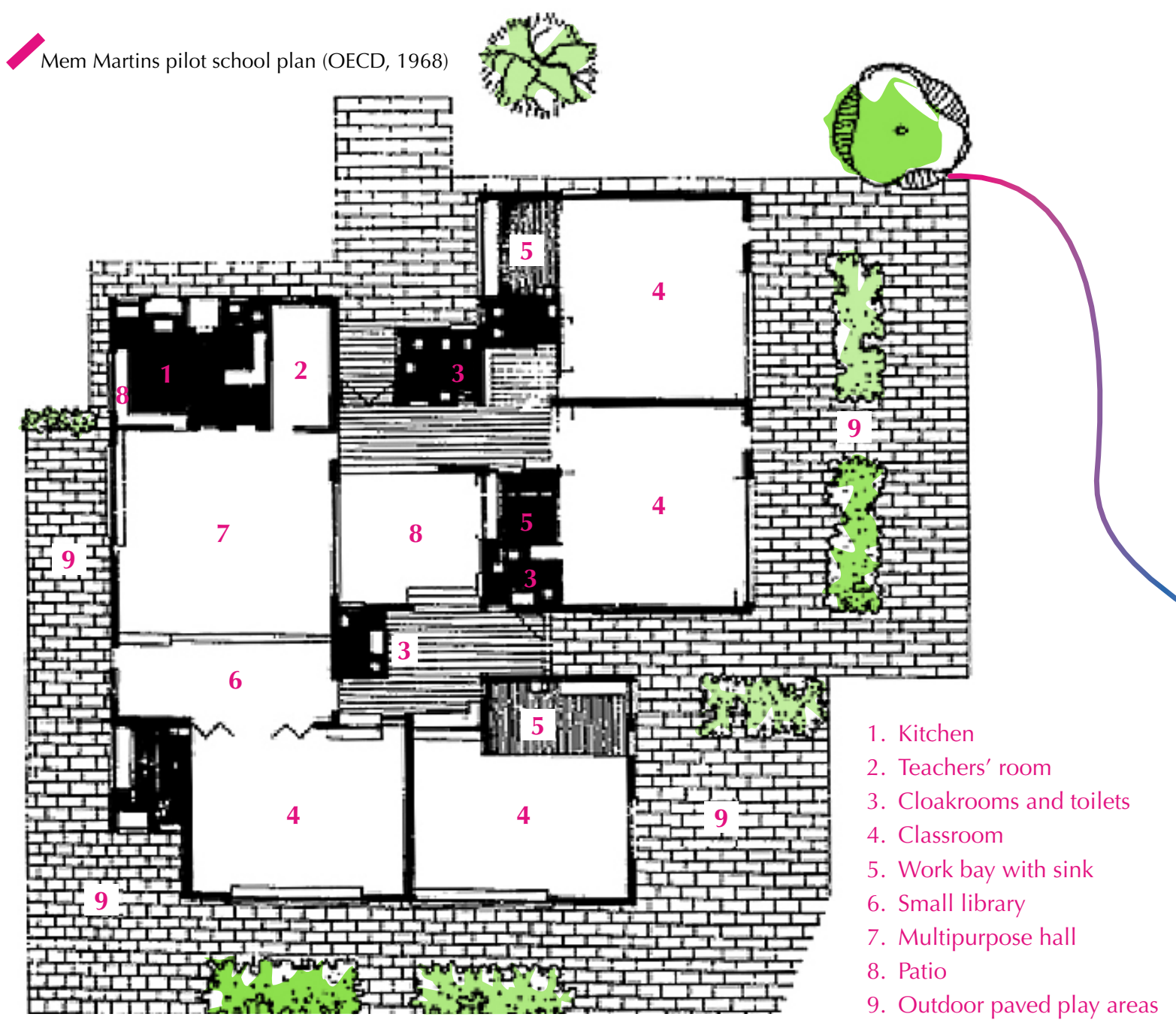




\section{THE "P3" PROJECT}

Maria do Carmo Matos, one of the architects for the Mem Martins pilot school, designed an open space project known today as "P3". ${ }^{1}$ Her designs (Matos, 1970) offered as much freedom as possible for various didactic techniques. She respected the principles of flexibility, both for further transformation of space and for different design solutions adapted to distinct sites and conditions.

The "P3" project had two main objectives:

1) pedagogical - creating a building that allowed several possibilities for individual and group teaching (for both small and large groups) and that permitted diverse student learning activities;

2) constructive - creating a building (with a nucleus of two or three "classrooms") that had repetitive modules and few variables in terms of construction elements, with the possibility to adapt to changing numbers of students and various site conditions.

The "P3" project schools were built throughout Portugal; a map from the Direcção-Geral do Ensino Básico (General-Directorate of Basic Education) showed 371 in July 1985. The project, with a nucleus that could vary in size and with an adaptable construction of modules that could be added or removed, produced a great variety of school buildings. Practically no two "P3" schools are identical.

But, as mentioned above, this building design was rejected and provoked resistance to the new teaching approaches that the space permitted. The noise level incited complaints, and teachers lacked the proper training to work in the new environment (they were accustomed to working alone, one teacher per class). As the open space was imposed upon them, the change was not well received and protests emerged against this type of schooling.

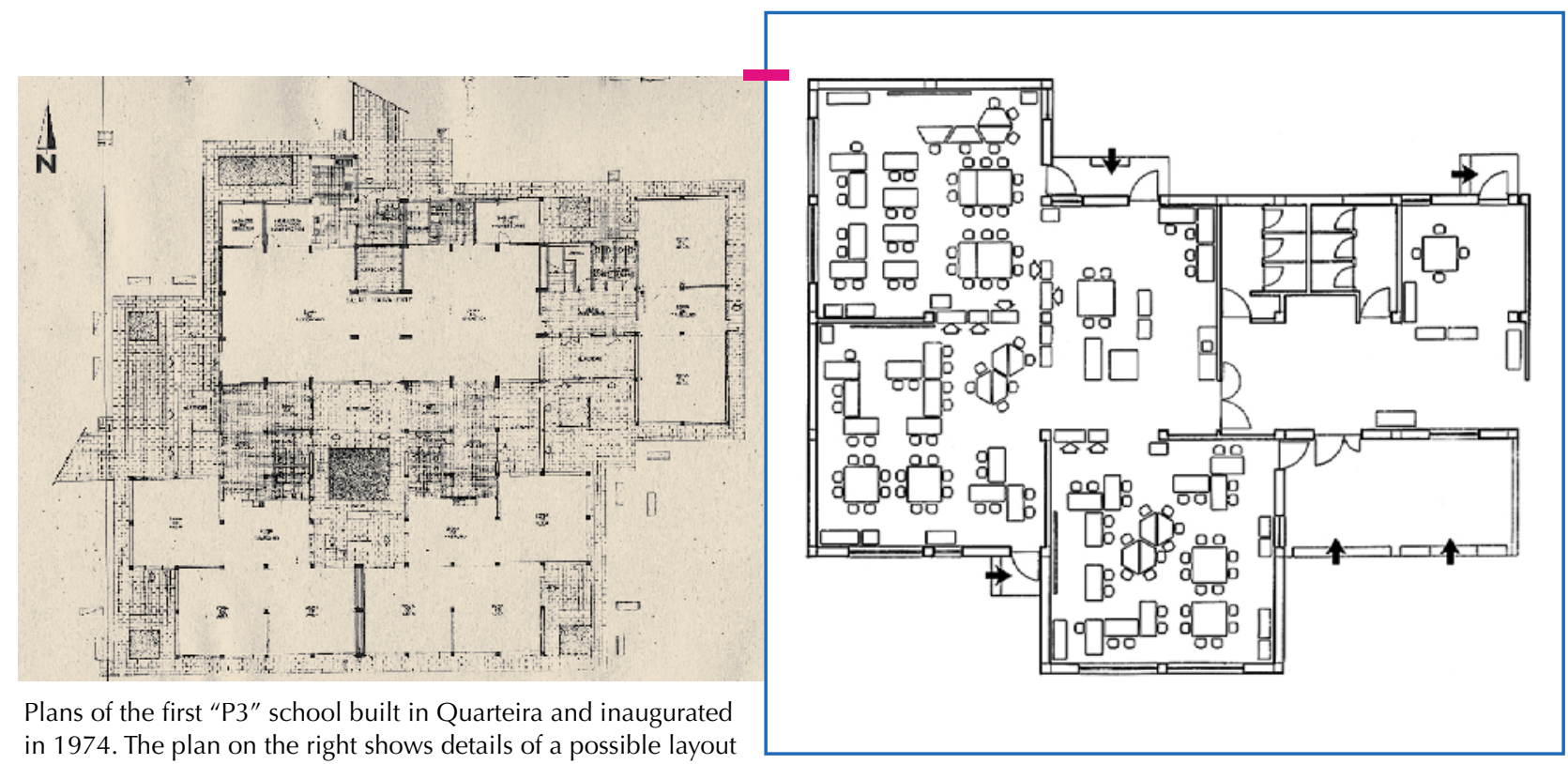

for a nucleus in open space (with three "classrooms").

1. Based on the studies made for the "P3" project, Maria do Carmo Matos also designed other open plan schools, commissioned by a number of city councils. Those projects were not called "P3" but were in fact the first open plan schools in Portugal. 


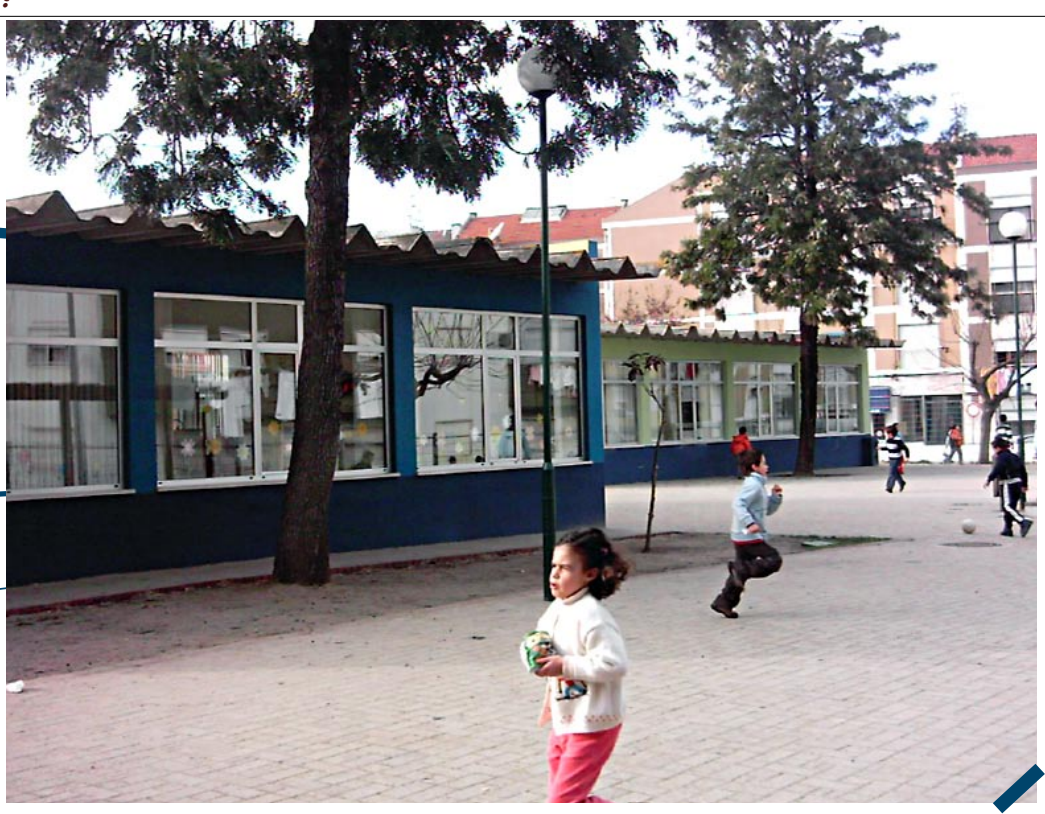

Soon walls were built inside the nuclei and the open space areas were successively closed. The pedagogical practices did not change with the architecture, and some teachers transformed the open plan design into traditional classrooms where they could teach more comfortably.

\section{ESCOLA DA PONTE: AN EXCEPTION}

Fortunately, not all the teachers in Portugal rejected the open plan design; some actually requested a building with its characteristics, as was the case of those who worked at the Ponte School:

The Ponte School is an open plan school, built thanks to the determination of the teachers, where no walls have been raised in the places where the architects had precluded them. The architecture plays an important part in meeting the objectives of the educative programme. (Pacheco, 2004)

This was confirmed by several sources, including interviews with José Pacheco (a teacher and pedagogical co-ordinator who played a key part in "creating" this school), articles that he wrote (Pacheco, 1998, p. 164; 2004) and other teachers (Pacheco et al., 2000): "One of the fundamental aspects of the school is related to the structure of the space, permitting students to move about for their daily work without depending on a teacher".

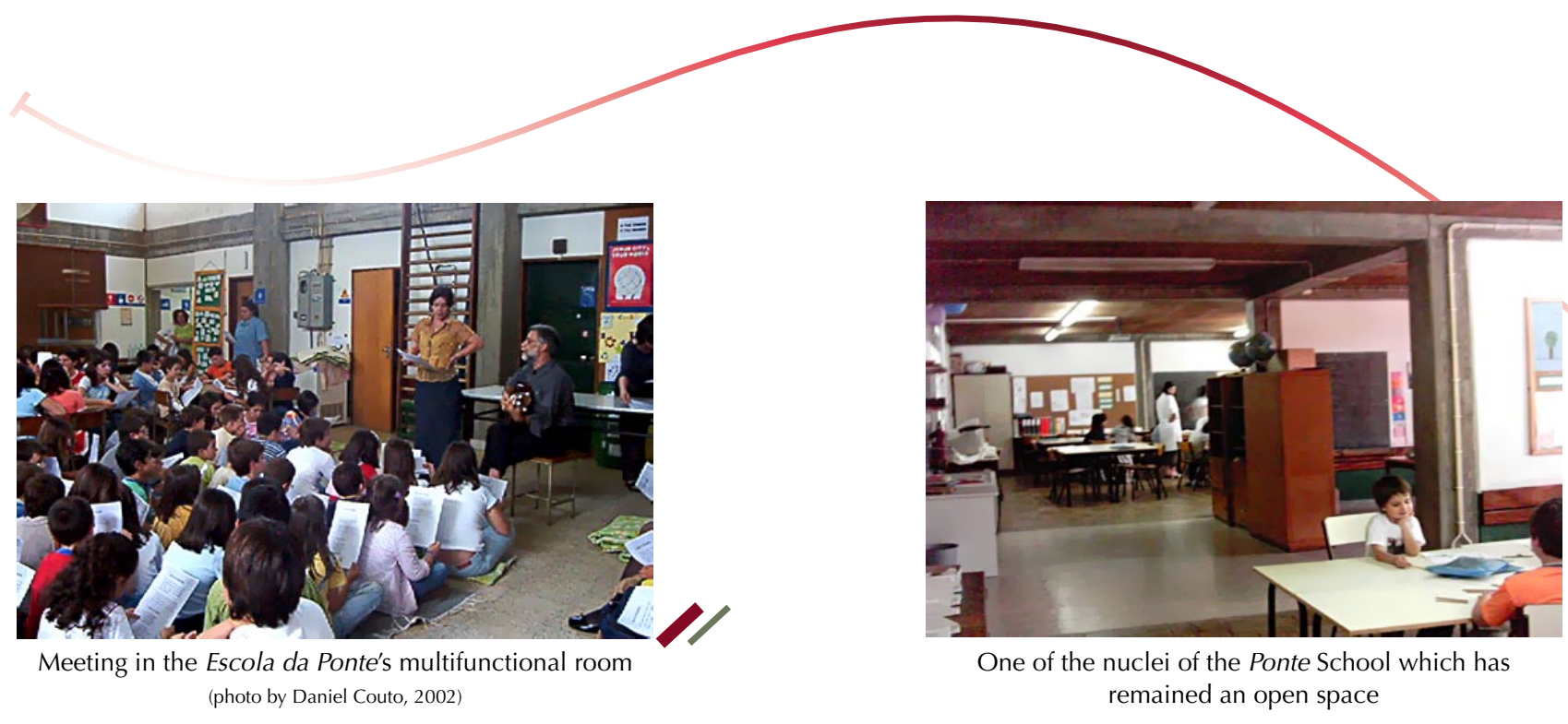


The Escola da Ponte is a good example of successful student results and low drop-out levels, as highlighted in the Case Studies of Promising Practice of the YOUTRAIN project ${ }^{2}$ co-ordinated by the University of Barcelona.

The Ponte project, originally called Fazer a Ponte (Build the Bridge), began in 1976 with pupils from Portugal's $1^{\text {st }}$ cycle of compulsory education (the first four years of education). In 2001, Escola da Ponte became an "integrated basic school", able to provide all levels of compulsory education (Guimarães and Oliveira, 2006).

The school comprises an Initiation space, a Consolidation space and an In-depth space:

In the Initiation space, work done by teachers is directed more towards the aims that are negotiated with pupils but not really shared due to age and the lack of pupils' experience in learning in accordance with these types of pedagogic methods. However, as pupils become acquainted with the methods selected in this school, namely in Consolidation and In-depth spaces, the teachers' support becomes less evident and it is based on the negotiation of learning through daily and fortnightly plans, on helping pupils to solve problems and to clarify any doubts that may occur, and on guiding pupils in the learning path which was previously defined. (Guimarães and Oliveira, 2006, p. 30)

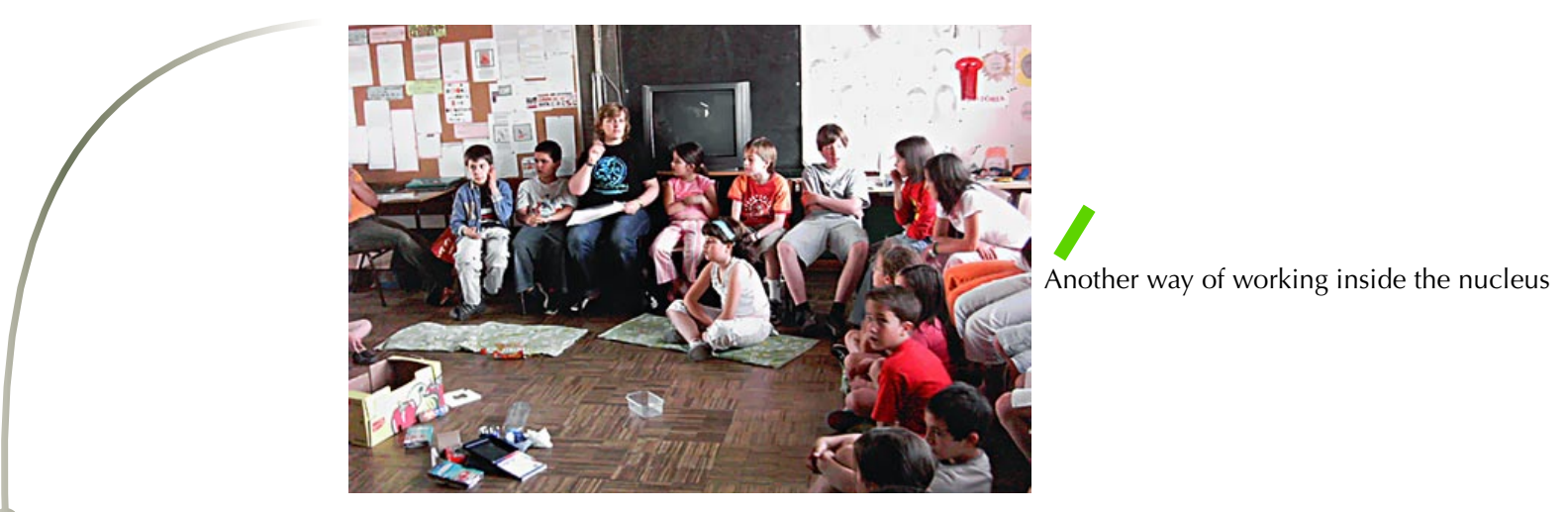

According to an external committee that evaluated the school and its educational programme, "the learning environment is considered stimulating, inviting, systematic, structured, active, diversified and significant for pupils, which seems to be very much appreciated by all actors, especially pupils" (Guimarães and Oliveira, 2006).

Paula Guimarães and Raquel Oliveira (2006) state that "space is a significant issue in this school". According to their observation and interviews, "the organization of space is a relevant innovation. There aren't any classrooms, not even the pupils have marked places to work from nor are they distributed by class groups according to their age". They continue, "this school is described as an open plan school not just due to the organization of space, but to the specificity of the pedagogic work pattern which allows this school to work differently from other schools".

2. Funded by the SOCRATES Programme from 2004 to 2006. 
The same authors quote from the report by the External Evaluation Committee: "when comparing pupils' learning outcomes with pupils from other Portuguese schools, in 2000 and 2001, these particular pupils had better performances in such subjects as Portuguese (reading and writing, amongst other areas) and mathematics. It must also be stressed that the schooling paths followed by those who attended this school show that from 1991/92 to 2000/01 the drop-out rates in compulsory education paths were much less dramatic than the average for Portuguese schools" (Guimarães and Oliveira, 2006).

They observe that some actors - political representatives, teachers, trade union representatives and researchers - disagree with "the excessive social valorisation concerning this experience that hinders the possibility of other experiences".

Continuing to examine both positive and negative aspects of the Ponte experience, Guimarães and Oliveira again cite the External Evaluation Committee report. It lists positive aspects such as the principles which support the project, the integration of the curriculum and the presence of motivated teachers in the school. On the negative side, they point to, for example, the number of pupils seemingly too high for the space available and an existing local conflict, namely between the school and local community actors, which seems to prevent the project from developing in the best way possible.

In addition, Guimarães and Oliveira refer to administrative constraints resulting from the school's relationship with the Ministry of Education and other state departments. They comment that "this pedagogic approach as well as the specific management rules adopted for this school created a singular status which on many occasions has brought more problems than solutions".

Even before this assessment, it was evident that the Escola da Ponte illustrated educational innovation in Portugal (see for example Canário, 2004). What made this case "successful" where others have failed is that the teaching staff was a part of that innovation. Instead of opposing the architecture, the teachers chose to incorporate it into their educational programme.

\section{References}

Brogden, M. (2007), "Plowden and Primary School Buildings: A Story of Innovation without Change", FORUM: for promoting 3-19 comprehensive education, Vol. 49, No. 1, pp. 55-66.

Brubaker, C. (1998), Planning and Designing Schools, McGraw-Hill, New York, p. 20.

Canário, R. (2004), "Uma inovação apesar das reformas" (One Innovation Despite Reforms), in R. Canário, F. Matos and R. Trindade (orgs.), Escola da Ponte. Defender a Escola Pública (Da Ponte School: Defending the Public School), Porto, Profedições, pp. 31-41.

Felgueiras, M. (2007), "A arquitectura da escola primária em Portugal nos séculos XIX e XX" (Primary School Architecture in Portugal in the $19^{\text {th }}$ and $20^{\text {th }}$ Centuries), in J. Gómez Fernández et al. (eds.), La escuela y sus escenarios. Actas de los IX Encuentros de Primavera en EI Puerto" (School and Different Scenarios: Minutes of the 9th Spring Meeting in El Puerto), Ayuntamiento de El Puerto de Santa Maria, El Puerto de Santa Maria, pp. 37-65.

Guimarães, P. and R. Oliveira (2006), "Escola da Ponte: The Innovative Pedagogic Approach of an Open School", in University of Barcelona/Centre of Research in Theories and Practices that Overcome Inequalities and University of Minho/Unit for Adult Education (orgs.), Responses to Challenges of Youth Training in the Knowledge Society. Case Studies of Promising Practice, University of Barcelona/Centre of Research in Theories and Practices that Overcome Inequalities, Barcelona, pp. 29-37. 
Hamilton, D. (1976), A Case Study of a New Scottish Open Plan School, The Scottish Council for Research in Education, Edinburgh.

Hargreaves, D. (1988), The Challenge for the Comprehensive School: Culture, Curriculum and Community, Routledge and Kegan Paul, London.

Hyland, T. (1980), "Philosophical and Historical Background", in N. Bennet et al., Open Plan Schools: Teaching, Curriculum, Design, NFER Publishing Company for the Schools Council, Windsor, p. 18.

Martinho, M. (2008), “'Open Plan School' - Another Conception of Educative Space”, in C. Fouad (ed.), Recueil des résumés des Sessions de Communications Libres, $15^{\text {th }}$ Congress of the AMSE-AMCE-WAER (Globalisation and Education: Towards a Society of Knowledge), Université Cadi Ayyad, Marrakech.

Matos, M. (1970), Escolas Primárias - "P3", Esquema de Solução, Memória Descritiva (Primary Schools - "P3", Solution Scheme, Descriptive Report), Ministério das Obras Públicas/Direcção-Geral das Construções Escolares, Lisbon.

OECD (1968), "Development and Economy in Educational Building - in Greece, Portugal, Spain, Turkey and Yugoslavia", project report, OECD, Paris.

Pacheco, J. (1998), "Fazer a Ponte" (Build the Bridge), in M. Moreira et al., Experiências inovadoras no ensino: inovação pedagógica (Innovative Teaching Experiences: Pedagogical Innovation), Instituto de Inovação Educacional, Lisbon, pp. 159-179.

Pacheco, J. (2004), "Uma escola sem muros" (A School without Walls), in R. Canário F. Matos and R. Trindade (orgs.), Escola da Ponte. Defender a Escola Pública (Da Ponte School: Defending the Public School), Profedições, Porto, p. 95.

Pacheco, J. et al. (2000), Fazer a Ponte (Build the Bridge), 8-minute videotape, Instituto de Inovação Educacional/ Escola Básica n. 1 da Ponte - Vila das Aves, Lisbon.

Pearson, E. (1972), Trends in School Design, Citation Press, New York, p. 36.

For more information, contact:

Miguel Martinho

Teacher/Educational Researcher

Av. D. João II

Lote 1.05.01, Ap. 303

1990-291 Lisbon

Portugal

E-mail:mimartinho@hotmail.com

José M. R. Freire da Silva

Architect

Ministry of Education

Av. 5 de Outubro 107, $7^{\circ}$ andar

1069-018 Lisbon

Portugal

E-mail: jose.freiresilva@sg.min-edu.pt 


\section{ORGANISATION FOR ECONOMIC CO-OPERATION AND DEVELOPMENT}

The OECD is a unique forum where the governments of 30 democracies work together to address the economic, social and environmental challenges of globalisation. The OECD is also at the forefront of efforts to understand and to help governments respond to new developments and concerns, such as corporate governance, the information economy and the challenges of an ageing population. The Organisation provides a setting where governments can compare policy experiences, seek answers to common problems, identify good practice and work to co-ordinate domestic and international policies.

The OECD member countries are: Australia, Austria, Belgium, Canada, the Czech Republic, Denmark, Finland, France, Germany, Greece, Hungary, Iceland, Ireland, Italy, Japan, Korea, Luxembourg, Mexico, the Netherlands, New Zealand, Norway, Poland, Portugal, the Slovak Republic, Spain, Sweden, Switzerland, Turkey, the United Kingdom and the United States. The Commission of the European Communities takes part in the work of the OECD.

OECD Publishing disseminates widely the results of the Organisation's statistics gathering and research on economic, social and environmental issues, as well as the conventions, guidelines and standards agreed by its members.

This work is published on the responsibility of the Secretary-General of the OECD. The opinions expressed and arguments employed herein do not necessarily reflect the official views of the Organisation or of the governments of its member countries. 